\title{
Development of Import Substitution of Goods as a Factor of Ensuring Competitiveness of Amur Region
}

\author{
Anjelica V. Vasilyeva* \\ Department of Economics and Management of the organization, Amur State University, Blagoveshchensk, Russia. \\ *Corresponding author. Email: vavangel@mail.ru
}

\begin{abstract}
The article considers the level of self-sufficiency of the region with the main types of agricultural products. On the basis of the analysis of resources and use of basic food products in the Amur region, it is concluded that the in-house production of some food products does not meet the needs of their domestic consumption. A large part of the region 's food resources is formed by the import of goods from other regions of the country, including imports. The high dependence of the region 's economy on imports poses a threat to the food security of the region 's population. In order to reduce the dependence of the region 's economy on imports and crises in foreign commodity markets, as well as to increase the competitiveness of the Amur region in domestic and foreign markets, the article considers the need to develop a strategy for import substitution of both food and non-food products.
\end{abstract}

Keywords: import substitution, food security, competitiveness of the region, level of self-sufficiency of the

region with food, coefficient of consumption dependence on supplies

\section{INTRODUCTION}

The rapid spread of coronavirus forced the state authorities to make non-standard management decisions to protect the health of the citizens of the country. One such solution was the forced closure of borders with China for a period. The end of trade with China clearly demonstrated the high dependence of the region 's economies on imports. The lack of raw materials and materials for the manufacture of products reduced the aggregate supply in the region, which was a prerequisite for the formation of a shortage of certain types of goods and services in the region. As is known, the shortage of goods leads to a significant increase in prices. In these circumstances, the issue of import substitution of goods, which is considered to be a factor in ensuring food security and competitiveness of the region, becomes relevant. This topic is especially relevant for the Amur region, a subject of the Far East Federal District of the Russian Federation, which occupies a border position and has the longest state border with China.

The purpose of the article is to study the state and necessity of import substitution of goods in the Amur region as a factor of ensuring its competitiveness.

\section{MAIN PART}

\subsection{Background}

In the Soviet, planned economy there was own production of goods and services, borders with other countries were closed. The issue of import substitution was not raised. It was only after privatization and the opening of State borders that a flow of foreign goods poured into the country. According to specialists, about $60 \%$ of goods became foreign. Many domestic producers went bankrupt because they were unable to compete with foreign firms. It was at this time that the concept of "import substitution" appeared [1].

Increased attention to import substitution in Russia has been observed since 2014, when in March 2014 President of the Russian Federation Vladimir Putin at the International Economic Forum in St. Petersburg identified import substitution as a key direction of the country 's new strategic policy. The decisive and key factor in the development of import substitution was the imposition by Western countries of economic sanctions against Russia in connection with the events in south-eastern Ukraine and the reunification of Crimea with Russia. As a response, the Russian Government imposed a ban on the import of a number of food, raw materials and agricultural products from countries involved in sanctions against Russia, in particular against the United States [ European Union countries, Canada, Australia, Norway [2, 3, 4].

The development of import substitution should contribute to the growth of own production of goods and services, reduction of dependence on import supplies and crisis situations in external commodity markets, increase of employment of the labour resources of the region, increase of real incomes of the population, increase of the population 's supply of products of own production, achievement of food security of the population of the region.

In economic literature a large number of researches of import substitution at the level of the state of $[5,6,7]$ is 
presented. However it is observed not enough researches devoted to the quantitative analysis of food resources and their uses in the regional scale of $[1,8,9,10]$. This is clearly true of the Amur region. For the region, the formation of import substitution strategy and food security are of paramount importance.

\subsection{Concept, essence, meaning of import substitution}

The concept of "import substitution" means replacing imports with domestically produced goods [6].

Analysis of literature showed that import substitution programs are effective in those types of economic activities where the region has clear competitive advantages, for example, cheap raw materials, large market capacity, established foreign economic cooperation.

The main task of import substitution is to establish competitive production facilities that produce high-quality and demanded goods.

As the experience of foreign countries has shown, first of all import substitution is implemented in agriculture of the region, where processing capacities are created quite quickly [5]. Import substitution is then introduced in industry for consumer goods.

The main direction of import substitution is the organization of production of those types of goods that have high added value.

The choice of the concept of import substitution implies the support of the authorities, which create a certain kind of incentives (organizational, financial, foreign trade, currency, etc.) for the development of certain types of economic activities in order to increase their competitiveness in the domestic and external market.
The most important prerequisites and ways to achieve the maximum effect of import substitution are: orientation towards the use of own raw material base; Technologically close production facilities; available human resources; advanced developments; Established logistics systems, etc.

\subsection{Statistical analysis of food resources and their use in the Amur region}

The Amur region is considered an agricultural region and, by some economic indicators, holds the leading position among the subjects of the Russian Federation. Thus, in the region every year the size of sown area in farms of all categories grows. In 2018, compared to 2010, the size of sown crop area increased by 491163 hectares or $62.1 \%$ [11]. The largest specific weight in cultivated area is taken away under commercial crops that makes $73.73 \%$ in 2018. At the same time practically all area of commercial crops is sowed by soy (99.86\% in 2018). It should be noted that the prevalence of the sown area under soybean is justified, as the Amurskaya region leads in the Russian Federation in the volume of soybean production.

In the structure of gross added value of the Amurskaya region, the share of agriculture in 2018 was $5.7 \%$. Although the share of agriculture in the gross regional product is decreasing slightly each year, this activity is strategically important and relevant for the development of the region.

Consideration of the development of import substitution in the region will begin with the issue of food supply to the population of the Amur region.

Table 1 shows the balance of resources and use of basic food products, in particular grain, by the population of the Amur region in 2010, 2015-2018 [11].

Table 1 Balance sheets of resources and use of basic food products (grain) by the population of Amur region in 2010, 20152018.

\begin{tabular}{|c|c|c|c|c|c|c|c|c|c|c|c|}
\hline \multirow{2}{*}{ Indicator } & \multicolumn{5}{|c|}{ Initial statistics, thousands of tons } & \multicolumn{2}{|c|}{$\begin{array}{l}\text { Absolute growth, } \\
\text { thousand tons }\end{array}$} & \multicolumn{3}{|c|}{ Chain growth rate, $\%$} & \multirow{2}{*}{$\begin{array}{c}\text { Basic } \\
\text { growth } \\
\text { rate, \% } \\
2018 / \\
2010\end{array}$} \\
\hline & $2010 \mathrm{y}$. & 2015 у. & 2016 y. & 2017 y. & 2018 y. & $\begin{array}{c}2018 / \\
2017 \\
\end{array}$ & $\begin{array}{c}2018 / \\
2010 \\
\end{array}$ & $\begin{array}{c}2016 / \\
2015 \\
\end{array}$ & $\begin{array}{c}2017 / \\
2016 \\
\end{array}$ & $\begin{array}{c}2018 / \\
2017 \\
\end{array}$ & \\
\hline \multicolumn{12}{|l|}{ Resources } \\
\hline $\begin{array}{l}\text { Inventory at the } \\
\text { beginning of the year }\end{array}$ & 202,3 & 301,8 & 307,7 & 373,0 & 331,0 & $-42,0$ & 128,7 & 102,0 & 121,2 & 88,7 & 163,6 \\
\hline Production & 130,6 & 351,6 & 475,2 & 395,1 & 360,3 & $-34,8$ & 229,7 & 135,2 & 83,1 & 91,2 & 275,9 \\
\hline $\begin{array}{l}\text { Import, including } \\
\text { import }\end{array}$ & 3,7 & 0,7 & 39,4 & 41,1 & 1,5 & $-39,6$ & $-2,2$ & 5628,6 & 104,3 & 3,6 & 40,5 \\
\hline Total resources & 336,6 & 654,1 & 822,3 & 809,2 & 692,8 & $-116,4$ & 356,2 & 125,7 & 98,4 & 85,6 & 205,8 \\
\hline \multicolumn{12}{|l|}{ Use } \\
\hline $\begin{array}{l}\text { Production } \\
\text { consumption }\end{array}$ & 69,1 & 77,9 & 81,3 & 96,3 & 118,9 & 22,6 & 49,8 & 104,4 & 118,5 & 123,5 & 172,1 \\
\hline It is processed & 133,5 & 200,6 & 265,6 & 248,6 & 196,1 & $-52,5$ & 62,6 & 132,4 & 93,6 & 78,9 & 146,9 \\
\hline Losses & 2,9 & 0,5 & 1,1 & 1,7 & 0,7 & $-1,0$ & $-2,2$ & 220,0 & 154,5 & 41,2 & 24,1 \\
\hline $\begin{array}{l}\text { Export, including } \\
\text { export }\end{array}$ & 23,4 & 66,8 & 100,7 & 131,0 & 112,8 & $-18,2$ & 89,4 & 150,7 & 130,1 & 86,1 & 482,1 \\
\hline Personal consumption & 0,5 & 0,6 & 0,6 & 0,6 & 0,6 & 0,0 & 0,1 & 100,0 & 100,0 & 100,0 & 120,0 \\
\hline Year-end inventory & 107,2 & 307,7 & 373,0 & 331,0 & 263,7 & $-67,3$ & 156,5 & 121,2 & 88,7 & 79,7 & 246,0 \\
\hline $\begin{array}{l}\text { Excess of production } \\
\text { over consumption }\end{array}$ & 61,0 & 273,1 & 393,3 & 298,2 & 240,8 & $-57,4$ & 179,8 & 144,0 & 75,8 & 80,8 & 394,8 \\
\hline
\end{tabular}


Thus, at the beginning of 2018 their volume amounted to 171.2 thousand tons. Potato production tends to decline during the period under review, although it remains at 200,000 tons per year. The share of potato supplies from other regions of the country, including imports from China, is insignificant and does not exceed 5.3\% in 2014, and in 2018 is only $2.82 \%$.

Figure 2 shows the dynamics of potato use in the Amur region for 2010-2018 [11].

During this period, the production consumption of potatoes decreased significantly by 37.3 thousand tons or by $38.2 \%$. Unlike production, personal consumption of potatoes decreased by only 2.9 thousand tons or $2.67 \%$.

Figure 2 shows that in 9 years the supply of potatoes to other regions of the country, including exports, has decreased significantly. Thus, potato export in 2018 decreased by 129.9 thousand tons or $90.9 \%$ compared to 2010. Potato cultivation and harvesting are significantly dependent on weather conditions in the region, so there are significant losses in potato use. In 2010-2018, potato losses range from 11 thousand tons in 2013 to 30.9 thousand tons in 2018. Comparison of potato resources and use in the Amurskaya region also indicates that inhouse potato production fully covers its production and personal consumption in the region.

Next, consider the availability of meat in the region. In the Amur region, the production of meat and meat products increased by 10.2 thousand tons or $31.78 \%$ in $2010-2018$. During the same period, personal consumption of meat and meat products increased by 4.1 thousand tons or $8.63 \%$ (Figure 3).

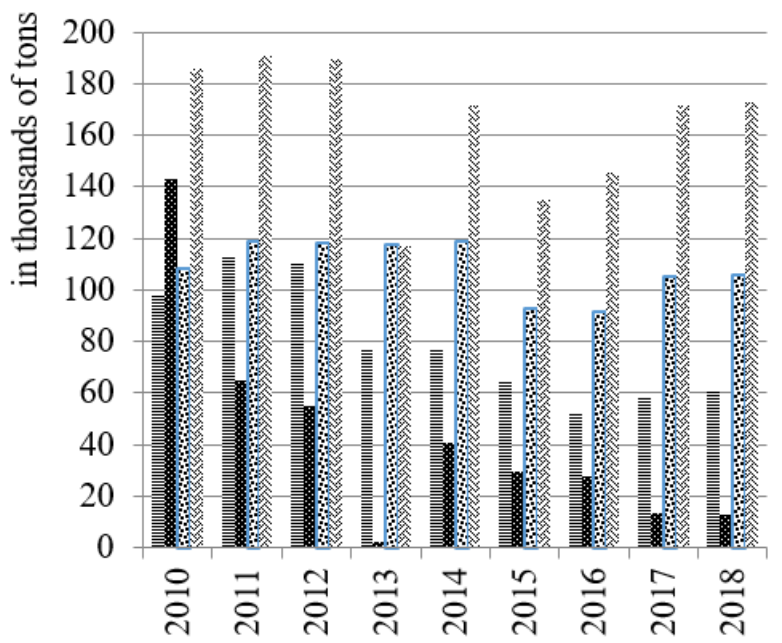

\section{豆Production consumption Export, including export \\ Personal consumption 㗪 Year-end inventory}

Figure 2 Dynamics of potato use in the Amur region for 2010-2018 


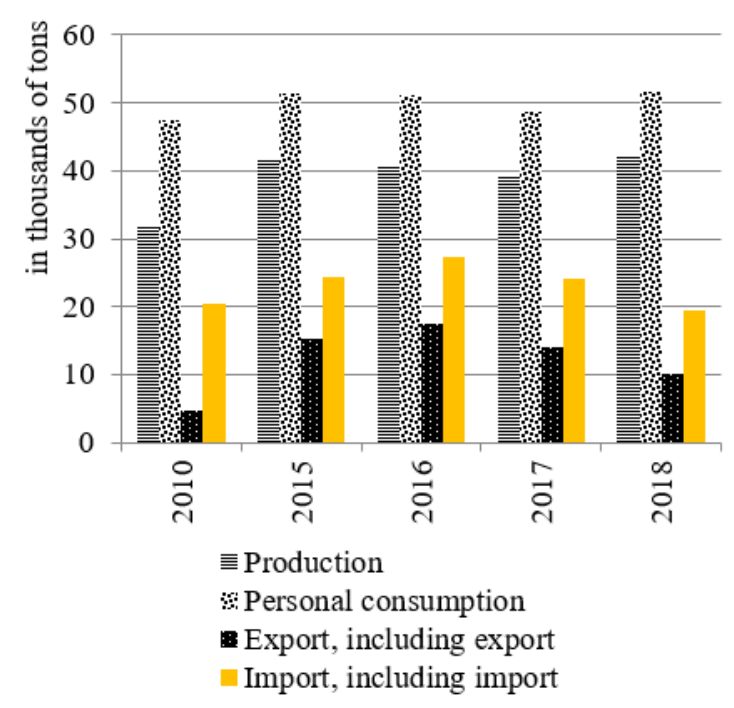

Figure 3 Dynamics of meat and meat products production and consumption in Amur region for 2010, 2015-2018

The high rate of production of meat and meat products does not cover the region 's need for consumption. The demand of the population and enterprises for meat is met by the import of products from other regions and countries. Thus, there is a threat to the food security of the population of the region. In 2018, about $18 \%$ of meat needs were met with imported products.

A similar situation is observed in the production and consumption of milk and dairy products, eggs and egg products, vegetables and melons, fruits and berries.

Figure 4 shows the excess of consumption of basic food by the population and enterprises of the Amur region over their own production in 2010, 2015-2018.

Fig. 4 shows that in-house production of a number of foods is not sufficient to meet the demand of consumers for domestic consumption of milk and dairy products, eggs and eggs, vegetables and melons, fruits and berries.

The missing need for food is provided by the import of goods from other regions of the country, as well as imports from foreign countries. In 2010-2018, the supply of milk and dairy products to the Amurskaya region increased significantly by 5.35 times, potatoes by 2.5 times, eggs and egg products by $43.8 \%$, vegetables and food melons by $21.13 \%$. Against this background, the supply of meat and meat products decreased by $5.4 \%$. These trends may indirectly indicate a decline in income and living standards of the population of the Amur region.

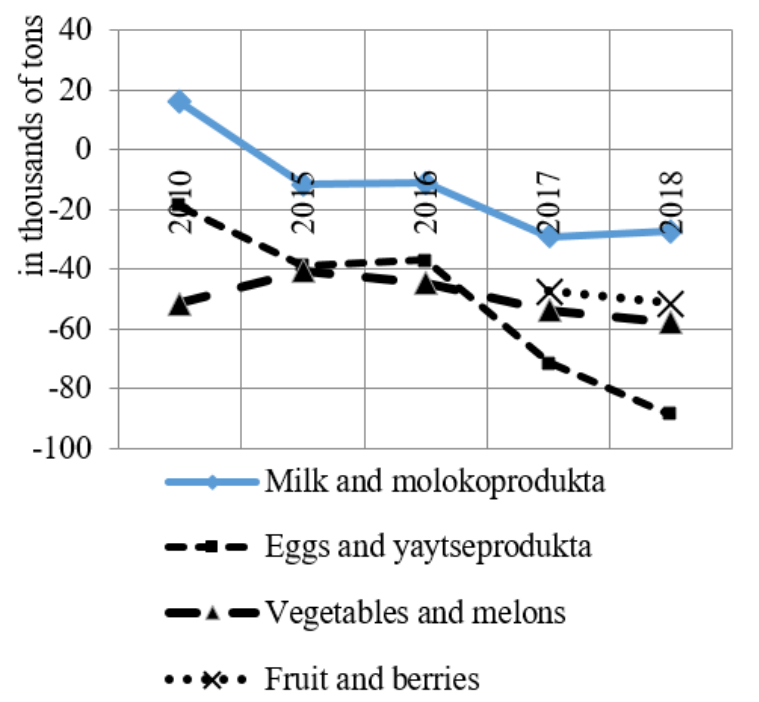

Figure 4 Dynamics of excess consumption of basic food products over production in Amur region in 2010, 20152018

\subsection{Analysis of self-sufficiency of the population of Amur region with basic food products}

Next, we will carry out an analysis of the self-sufficiency of the population of the region with basic food. For this purpose, we calculate two indicators: 1) the level of selfsufficiency of the region with food as a ratio of their regional production to consumption (the sum of production, personal consumption and losses); 2) ratio of consumption to supply, including imports as a ratio of income to production and personal consumption [6]. The results of the calculations are shown in Table 2-3.

As shown in Table 2, the population of the Amur region is provided with grain and potatoes in sufficient quantity. Food shortages exist for the rest of the food.

Table 2 Dynamics of the level of self-sufficiency of the population of Amurskaya region with food for 2010, 2015-2018.

\begin{tabular}{|c|c|c|c|c|c|c|c|}
\hline Basic Food Products & $\begin{array}{c}\text { Threshold } \\
\text { values }\end{array}$ & 2010 y. & 2015 y. & 2016 y. & 2017 y. & 2018 y. & $\begin{array}{c}\text { Absolute } \\
\text { increase } 2018 \text { / } \\
\text { 2010, p.p. }\end{array}$ \\
\hline Grain & 95 & 63,40 & 125,75 & 136,32 & 113,80 & 113,91 & 50,51 \\
\hline Potatoes & 95 & 117,91 & 117,51 & 118,35 & 112,20 & 102,03 & $-15,88$ \\
\hline Meat and meat products & 85 & 67,58 & 81,17 & 79,84 & 80,12 & 81,98 & 14,4 \\
\hline Milk and molokoprodukta & 90 & 111,73 & 91,81 & 92,03 & 80,94 & 82,37 & $-29,36$ \\
\hline Eggs and yaytseprodukta & $\ldots$ & 92,85 & 83,96 & 84,36 & 74,09 & 69,29 & $-23,56$ \\
\hline Vegetables and melons & $\ldots$ & 49,95 & 57,29 & 52,38 & 50,46 & 46,59 & $-3,36$ \\
\hline Fruit and berries & $\ldots$ & 8,3 & 6,4 & 5,5 & 6,1 & 6,88 & $-1,42$ \\
\hline
\end{tabular}


Table 3 Dynamics of consumption dependence factor on supplies, including imports for 2010, 2015-2018

\begin{tabular}{|c|c|c|c|c|c|c|c|}
\hline \multicolumn{8}{|c|}{ As a percentage } \\
\hline Basic Food Products & $2010 \mathrm{y}$ & 2015 y. & 2016 y. & 2017 y. & 2018 y. & $\begin{array}{c}\text { Absolute } \\
\text { increase } 2018 \text { / } \\
\text { 2017, p.p. }\end{array}$ & $\begin{array}{c}\text { Absolute } \\
\text { increase } 2018 \text { / } \\
\text { 2010, p.p. }\end{array}$ \\
\hline Grain & 5,32 & 0,89 & 48,11 & 42,41 & 1,26 & $-41,15$ & $-4,06$ \\
\hline Potatoes & 2,09 & 1,90 & 6,40 & 10,23 & 6,51 & $-3,72$ & 4,42 \\
\hline Meat and meat products & 43,16 & 47,18 & 53,23 & 49,59 & 37,60 & $-11,99$ & $-5,56$ \\
\hline Milk and molokoprodukta & 14,86 & 37,92 & 53,09 & 79,88 & 70,09 & $-9,79$ & 55,23 \\
\hline Eggs and yaytseprodukta & 26,85 & 16,58 & 15,43 & 28,50 & 36,72 & 8,22 & 9,87 \\
\hline Vegetables and melons & 51,41 & 44,08 & 54,35 & 60,13 & 59,33 & $-0,8$ & 7,92 \\
\hline Fruit and berries & & & & 100,61 & 93,09 & $-7,52$ & \\
\hline
\end{tabular}

«...» data are absent

Over the period 2010-2018, the largest increase in the level of self-sufficiency of the region with food products is observed for grain (50.51 p.p.). Also, the internal supply of meat and meat products to the population of the region has increased (the absolute increase was 14.4 p.p.). The greatest decrease in self-reliance of the region food is observed on milk and molokoprodukta (-29.36 items). Further eggs and yaytseprodukta (-23.56 items), then potatoes ( -15.88 items) follow. On vegetables the level of self-reliance of the population of the region fluctuates from $46.59 \%$ in 2018 up to $57.29 \%$ in 2015 . The average level of security of the population of the Amur region with vegetables is $51.33 \%$. To the least extent, the population of the Amur region is provided with its own production of fruits and berries. There is a stable low level - only $6.88 \%$ for 2018.

Table 3 shows that the greatest dependence of food consumption on supplies is observed for fruits and berries (93.09\% in 2018), milk and milk products $(70.09 \%$ in 2018), vegetables and melons (59.33\% in 2018), eggs and eggs (36.72\% in 2018), meat and meat products (37.6\%). Grain and potatoes are the least dependent on supplies, including imports. During the period under review, dependence on milk, eggs and vegetables increased significantly, as evidenced by the positive value of the consumption dependence factor on supplies.

It should also be noted that meat and meat products, milk and milk products, eggs and egg products, vegetables and melons, fruits and berries, the volume of agro-food products imported into the region far exceeds the volume of exported products. During the period under review, the Amur region maintains a constant negative balance in the ratio of food exports to imports.

\section{IMPORT SUBSTITUTION STRATEGY IN THE AMUR REGION}

The high level of dependence of the Amur region economy on supplies is observed not only for food products. There is a high dependence of the economy of the region on supplies, in particular, on imports of machine-building products, textile-sewing, leather-plating products, chemical products of consumer purpose, pharmaceutical products, woodworking, etc. [5].
In the context of the current economic situation and the high dependence on external markets, it is necessary to develop basic mechanisms aimed at stimulating domestic production [10]. In this regard, there is a long-standing need to develop an import substitution strategy in the region.

The main objective of the strategy of import substitution of goods is to increase own production of goods, which should contribute to reducing dependence on imports and ensuring food security of the population of the region.

Development of import substitution will allow regional producers to expand the market and master previously inaccessible market segments by increasing the rate and volume of goods output [6].

In the context of crisis situations in foreign markets, each subject of the Russian Federation should implement its import substitution strategy on the basis of available competitive advantages and production capabilities. In the Amur region, such competitive advantages are the availability of production facilities, including sown areas, favourable climatic conditions, proximity to China.

The development of import substitution contributes to increasing the utilization of own production capacities, establishing the production of related and supporting industries, increasing the level of self-sufficiency of the population with products of own production, increasing the employment of the population, reducing unemployment and increasing the level of purchasing power of citizens.

In order to implement the import substitution strategy in the Amur region, it is necessary to carry out reconstruction of existing enterprises and renewal of fixed production funds; Creation and development of processing and processing plants focused on import substitution and export of products; Promoting direct investment flows to the real sector of the region 's economy; Changing the structure of export of goods, in particular substitution of export of raw materials and products of primary processing by export of finished products.

The economic effect of the import substitution strategy in the Amur region will be expressed in the increase of revenues from the sale of products of own production of local enterprises, which should lead to the increase of wages of employees of enterprises, modernization of production, introduction of innovative technologies, increase of taxable base of enterprises. 
jekonomicheskih mer v celjah obespecheniya bezopasnosti Rossijskoj Federacii». URL: http://www.consultant.ru/document/ cons_doc_LAW_166922

[4] Postanovlenie Pravitel'stva RF ot 7 avgusta 2014 g. № 778 «O merah po realizacii ukazov Prezidenta Rossijskoj Federacii ot 6 avgusta 2014 g. № 560». URL: http://www.consultant.ru/ document/cons_doc_LAW_167001

[5] L.A. Strizhkova, Using «input-output» tables in estimating the dependence of Russian economy on import and import substitution processes, in: Voprosy statistiki, vol. 5, 2016, pp. 3-22. DOI: https://doi.org/10.34023/2313-6383-2016-0-5-3-22

[6] E.S. Pozhydayeva, Food import substitution in Russia: a statistical study, in: Voprosy statistiki, vol. 10, 2016, pp. 57-63. DOI: https://doi.org/10.34023/23136383-2016-0-10-57-63

[7] O.N. Voronkova, The process of import substitution in the context of ensuring strategic competitiveness of the region in the global economics, in: Financial studies, vol. 3 (56), 2017, pp.123-131.

[8] R.N. Galikeev, Import substitution as a factor in ensuring food security of the region, in: Bulletin of the Altai Academy of Economics and Law, vol. 12, 2019, pp. 61-65.

[9] V.L. Somov, V.A. Markov, Statistical analysis of import substitution prospects and competitive advantages of the real sector of economy in the Saratov region, in: Voprosy statistiki, vol. 3, 2016, pp. 65-71. DOI: https://doi.org/10.34023/2313-6383-2016-0-3-6571

[10] S.A. Shulmin, Yu. R. Lutvullin, Development of import substitution as a factor of thecompetitiveness of the region in ensuring food security ofthe country, in: Innovations and investments, vol. 12, 2019, pp. 254257.

[11] Amur Statistical Yearbook 2019: Statistical Collection/Amurstat. - Blagoveshchensk, 2019. 375 p.
[3] Ukaz Prezidenta Rossijskoj Federacii ot 6 avgusta 2014 g. № 560 «O primenenii otdel'nyh special'nyh 